\title{
ANALISA PERUBAHAN KERAPATAN MANGROVE BERDASARKAN NILAI NORMALIZED DIFFERENCE VEGETATION INDEX MENGGUNAKAN CITRA LANDSAT 8 (STUDI KASUS: PESISIR UTARA SURABAYA)
}

\author{
Bangun Muljo Sukojo', Yurike Nisa Arindi² \\ 1,2 Departemen Teknik Geomatika, FTSLK-ITS, Kampus ITS Sukolilo, Surabaya, 60111, Indonesia \\ e-mail: ${ }^{1}$ bangunms@gmail.com
}

\begin{abstract}
Abstrak
Dinamika lingkungan di wilayah Pesisir Utara Surabaya mengakibatkan terjadinya perubahan kerapatan mangrove di kawasan tersebut. Mangrove memiliki fungsi ekologis dan ekonomis bagi makhluk hidup. Mengingat peran penting mangrove bagi wilayah pesisir, diperlukan adanya pengelolaan yang tepat untuk menjaga eksistensi mangrove tersebut. Ekosistem mangrove merupakan salah satu obyek yang dapat diidentifikasi menggunakan teknologi penginderaan jauh. Teknologi tersebut dapat me-monitoring kerapatan mangrove menggunakan perhitungan algoritma indeks vegetasi. Dalam penelitian ini, data citra satelit yang digunakan adalah citra Landsat 8 multitemporal selama tahun 2016-2018. Sedangkan algoritma indeks vegetasi yang digunakan adalah NDVI. Algoritma tersebut bertujuan untuk mengetahui tingkat kerapatan mangrove khususnya di Pesisir Utara Surabaya. Citra hasil klasifikasi akan diuji akurasi menggunakan data kerapatan tajuk pada 34 titik sampel di lapangan. Uji klasifikasi algoritma NDVI menghasilkan nilai Overall Accuracy sebesar 94,12\%. Sehingga hasil klasifikasi citra tersebut dapat digunakan untuk proses selanjutnya. Berdasarkan hasil klasifikasi perhitungan algoritma NDVI pada citra Landsat 8, luas ekosistem mangrove selama tahun 2016-2018 terus mengalami penurunan. Luas mangrove berdasarkan NDVI tahun 2016-2018 sebesar 184,59, 184,14 dan 183,60 hektar. Selain itu, hasil penelitian menunjukkan bahwa korelasi (R) antara NDVI dengan kerapatan jenis menghasilkan nilai korelasi yang kuat yakni 0,8. Selain itu, hasil perhitungan korelasi indeks vegetasi dengan sampel parameter air di lapangan menunjukkan bahwa sampel salinitas memiliki korelasi ( $R$ ) sangat baik terhadap nilai NDVI sebesar 0,90 . Sedangkan untuk korelasi antara NDVI dengan pH berkorelasi (R) negatif yakni sebesar $-0,67$.
\end{abstract}

Kata kunci : Kerapatan, Landsat 8, NDVI

\begin{abstract}
Environmental dynamics in the North Coast of Surabaya caused changes in mangrove density. Mangroves have ecological and economic functions for living things. Given the important role of mangrove for coastal areas, it is necessary to have a proper management to maintain the existence of the mangrove. The mangrove ecosystem is one of the objects that can be identified using remote sensing technology. The technology can monitor the mangrove density using vegetation index calculation algorithm. In this research, satellite image data used is multitemporal Landsat 8 imagery during year 2016-2018. While the vegetation index algorithm used is NDVI. This algorithm aims to determine the level of mangrove density, especially in the North Coast of Surabaya. The classified image will be tested for accuracy using tree density data at 34 sample points in the field. NDVI algorithm classification test resulted in Overall Accuracy value of $94.12 \%$. Thus, the results of the image classification can be used for the next process. Based on the results of NDVI algorithm classification on Landsat 8 imagery, the area of mangrove ecosystem during 20162018 continues to decrease. The mangrove area based on NDVI classification during 2016-2018 are 184,59, 184,14 and 183,60 hectares. In addition, the results showed that the correlation (R) between NDVI with the density of the species produced a strong correlation value of 0.8 . In addition, the result of correlation calculation of vegetation index with water parameter samples in the field showed that salinity samples have a very good correlation $(R)$ to the NDVI value of 0.90. As for the correlation between NDVI and $\mathrm{pH}$ correlated (R) negative is equal to -0.67 .
\end{abstract}

Keywords : Density, Landsat 8, NDVI 


\section{PENDAHULUAN}

Perubahan yang terjadi dikawasan pesisir disebabkan karena adanya aktifitas manusia yang melakukan pembangunan ke arah pesisir. Pembangunan wilayah pesisir menyebabkan perubahan fungsi lahan menjadi kawasan pemukiman, industri maupun tambak, serta adanya penebangan pohon ilegal menyebabkan kerusakan ekosistem mangrove (Landgrebe, 2003). Ekosistem mangrove memiliki fungsi ekologis dan ekonomis bagi makhluk hidup. Secara ekologis, mangrove dapat berfungsi sebagai tempat hidup, tempat mencari makan biota laut serta sebagai daerah pemijahan. Sedangakan secara ekonomis, mangrove dapat digunakan sebagai bahan bangunan, lahan tambak dan obyek wisata. Ekosistem mangrove banyak terdapat di wilayah peralihan antara daratan dan lautan yang menyebabkan ekosistem tersebut rentan terhadapat kerusakan maupun gangguan.

Mangrove merupakan salah satu obyek yang dapat diidentifikasi menggunakan teknologi penginderaan jauh. Oleh karena, letak geografis ekosistem mangrove yang berada pada daerah peralihan antara darat dan laut sehingga memberikan efek perekaman yang khas jika dibandingkan obyek vegetasi darat lainnya (Purwadhi, 2001). Pada umumnya untuk deteksi vegetasi digunakan transformasi indeks vegetasi. Indeks vegetasi adalah suatu transformasi matematis yang melibatkan beberapa saluran sekaligus untuk menghasilkan citra baru yang lebih representatif dalam menyajikan aspekaspek yang berkaitan dengan vegetasi. Sehingga dalam penelitian ini akan dilakukan pengkajian tentang perubahan kerapatan ekosistem mangrove menggunakan algoritma indeks vegetasi pada data penginderaan jauh. Algoritma NDVI akan diterapkan terhadap data citra satelit multitemporal Landsat 8 tahun 2016-2018. Selain itu, penelitian ini bertujuan untuk mengetahui tingkat korelasi antara indeks vegetasi dengan data lapangan.

\section{METODE}

\section{Lokasi Penelitian}

Lokasi penelitian ini dilakukan di kawasan mangrove Pesisir Utara Surabaya, Jawa Timur. Secara geografis, lokasi penelitian ini terletak pada koordinat $7^{\circ} 11^{\prime} 35,77^{\prime \prime}-7^{\circ} 12^{\prime} 30,1^{\prime \prime}$ LS dan $112^{\circ} 39^{\prime} 47,57^{\prime \prime}-112^{\circ} 46^{\prime} 42,81^{\prime \prime}$ BT.

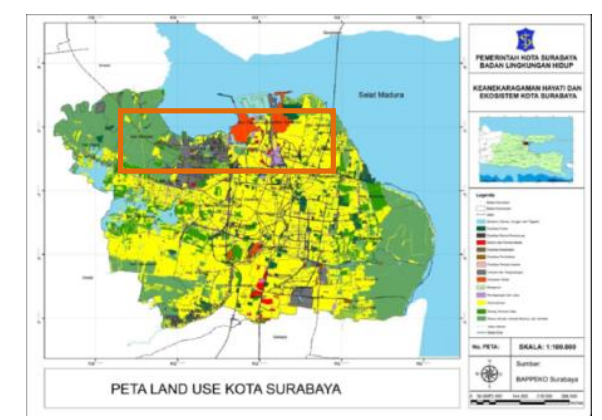

Gambar 1. Lokasi Penelitian (Bappeko, 2014)

\section{Data dan Peralatan}

Data yang digunakan dalam penelitian ini adalah Landsat 8 tahun 2016-2018, Data uji sampel parameter, Data Spectral Ground (NIR foto), Peta RBI skala 1:25.000. Sedangkan peralatan yang digunakan adalah Kamera Inframerah (NIR), Pesawat UAV (drone), GPS Handheld, Refraktometer, $\mathrm{pH}$ meter, laptop, perangkat lunak pengolah citra satelit.

\section{Tahap Pengolahan Data}

Adapun tahapan pengolahan data dalam penelitian antara lain sebagai berikut:

a. Pra Pengolahan

Tahap awal dalam pengolahan data citra yakni melakukan perbaikan citra menggunakan komposit band 564 untuk memudahkan identifikasi mangrove.

b. Pembuatan Desain Jaring

Desain jaring menentukan kekuatan geometrik dari persebaran titik GCP. Sehingga kekuatan jaring perlu dihitung juga. Apabila nilai SoF (kekuatan jaring) $\leq 1$, maka kekuatan desain jaring telah masuk toleransi sehingga dapat dipergunakan untuk tahap selanjutnya (Abidin, 2002).

c. Koreksi Geometrik

Koreksi geometrik merupakan proses perbaikan posisi citra agar sesuai dengan koordinat di lapangan. Koreksi geometrik pada Landsat 8 menggunakan bantuan peta RBI dengan metode Image to Map. Dalam koreksi geometrik harus memperhatikan nilai RMSE. Apabila nilai RMSE lebih kecil dari 1 piksel (Purwadhi, 2001), maka 
koreksi tersebut telah berhasil dilakukan dan dapat dipergunakan untuk tahap selanjutnya.

d. Koreksi Radiometrik

Koreksi radiometrik bertujuan untuk memperbaiki nilai-nilai piksel yang tidak sesuai dengan nilai pantulan atau pancaran spektral obyek yang sebenarnya. Koreksi radiometrik terdiri dari dua tahap, antara lain kalibrasi radiometrik dan koreksi atmosfer. Koreksi atmosfer menggunakan metode 6SV.

e. Perhitungan Algoritma Indeks Vegetasi

Indeks vegetasi merupakan suatu algoritma yang dapat mencerinkan kondisi kesehatan dan kerapatan vegetasi. Indeks vegetasi yang digunakan dalam penelitian ini adalah NDVI. NDVI adalah indeks vegetasi yang paling umum digunakan (Sugiyono, 2008). Berikut adalah algoritma NDVI (Landgrebe, 2003):

$$
\text { NDVI }=\frac{p \text { NIR }-p \text { RED }}{p \cdot \operatorname{NIR}+p \text { RED }}
$$

Keterangan:

NIR : Nilai reflektan band Near-Infrared

RED : Nilai reflektan band Red

f. Klasifikasi Citra

Citra Landsat 8 diklasifikasi berdasarkan rentang nilai indeks vegetasi NDVI. Klasifikasi citra terbagi menjadi empat kelas yakni mangrove rapat, mangrove sedang, mangrove jarang dan non mangrove.

g. Pengambilan Sampel Parameter

Sampel parameter yang diambil dilapangan antara lain sampel parameter spectral ground serta data kerapatan tegakan sebagai data validasi lapangan. Pengambilan sampel parameter kerapatan tegakan menggunakan metode sampel plot dengan membuat plot 10×10 meter yang ditempatkan secara acak (random). Selain itu, dilakukan pengambilan sampel air yakni salinitas dan $\mathrm{pH}$.

h. Uji Klasifikasi

Uji klasifikasi dilakukan untuk menguji hasil klasifikasi dengan akurasi tertentu. Akurasi tersebut dapat dilihat melalui matriks kesalahan (confussion matrix). Hasil klasifikasi dianggap benar apabila nilai Overall Accuracy lebih dari 85\% (BIG, 2014).

\section{HASIL DAN PEMBAHASAN}

\section{Perhitungan Strength of Figure (SoF)}

Berdasarkan desain jaring yang telah dibuat, hasil perhitungan SoF dari desain jaring Citra Landsat 8 adalah sebesar 0,23 . Apabila nilai kekuatan desain jaring semakin kecil mendekati 1 maka akan semakin baik dan sebaliknya (Abidin, 2002).

\section{Koreksi Geometrik}

Koreksi geometrik pada citra Landsat 8 dilakukan dengan menggunakan acuan peta RBI skala 1:25000. Koreksi dilakukan secara Image to Map. Koreksi dari Landsat 8 tahun 2016-2018 menggunakan 15 titik GCP sehingga diperoleh nilai RMSE berturut-turut sebesar 0,114, 0,108 dan 0,132 . Seluruh nilai RMSE kurang dari 1 piksel, sehingga masuk toleransi (Danoedoro, 1996).

\section{Perhitungan Indeks Vegetasi}

Indeks vegetasi yang digunakan dalam pengolahan data adalah algoritma NDVI. Rentang nilai algoritma tersebut berkisar antara -1 dan +1 , dimana nilai tersebut mencerminkan kondisi, karakteristik dan jenis suatu vegetasi (Ginting, 2004).

Tabel 1. Perhitungan Nilai NDVI Citra Landsat 8

\begin{tabular}{cccc}
\hline \multirow{2}{*}{ Tahun } & \multicolumn{3}{c}{ NDVI } \\
\cline { 2 - 4 } & Min & Max & $\begin{array}{c}\text { Standart } \\
\text { Deviasi }\end{array}$ \\
\hline 2016 & $-1,000$ & 1,000 & 0,735 \\
2017 & $-1,000$ & 1,000 & 0,451 \\
2018 & $-0,104$ & 0,821 & 0,226 \\
\hline
\end{tabular}

\section{Klasifikasi Citra}

Citra Landsat 8 diklasifikasi berdasarkan nilai rentang indeks vegetasi yang didapat dari perhitungan algoritma. Klasifikasi citra membagi kelas kerapatan berdasarkan rentang nilai NDVI. Hasil klasifikasi tersebut terbagi menjadi empat kelas yang terdiri dari kelas non mangrove, mangrove rapat, mangrove sedang dan mangrove jarang. Berikut adalah hasil perhitungan luas kerapatan mangrove menggunakan klasifikasi citra seperti Tabel 2 berikut:

Tabel 2. Luas Kerapatan Mangrove dengan Klasifikasi Nilai NDVI

\begin{tabular}{ccccc}
\hline \multirow{2}{*}{ Tahun } & \multicolumn{3}{c}{ Luas Kerapatan (ha) } & Luas \\
\cline { 2 - 4 } & Jarang & Sedang & Rapat & Total \\
\hline 2016 & 27,63 & 56,79 & 100,17 & 184,59 \\
2017 & 39,51 & 61,20 & 83,43 & 184,14 \\
2018 & 38,97 & 60,21 & 84,42 & 183,60 \\
\hline
\end{tabular}


Dari hasil perhitungan tersebut, luas kerapatan dari tahun ke tahun menunjukkan adanya perubahan kerapatan mangrove. Berdasarkan klasifikasi NDVI pada tahun 20162018 didapatkan luas kerapatan berturut-turut sebesar 184,59, 184,14 dan 183,60 hektar.

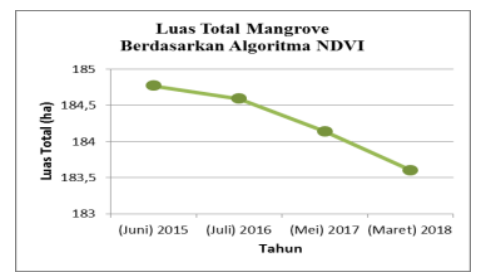

Gambar 2. Luas Total Mangrove Berdasarkan Algoritma NDVI

Selama tahun 2016-2018, luas total mangrove Pesisir Utara terus mengalami penurunan luas kerapatan seperti Gambar 2. Total perubahan luas mangrove selama tahun 2016-2018 berdasarkan algoritma NDVI sebesar 0,99 hektar. Hal ini dipengaruhi oleh adanya aktivitas manusia seperti alih fungsi lahan mangrove menjadi kawasan tambak, pembangunan dermaga baru hingga pemanfaatan pohon mangrove secara langsung (Ratnasari, 2017).

\section{Uji Klasifikasi}

Dari hasil klasifikasi yang telah dilakukan sebelumnya dan validasi data di lapangan, selanjutnya dihitung keakuratan pemetaan tersebut menggunakan matriks kesalahan (confussion matrix) seperti Tabel 1. Uji klasifikasi citra dilakukan pada 34 titik. Dari hasil uji klasifikasi nilai NDVI didapatkan nilai Overall Accuracy sebesar 94,12\%. Hasil uji klasifikasi pada kedua algoritma, menunjukkan hasil Overall Accuracy lebih dari 85\% sehingga hasil klasifikasi citra ini dapat digunakan untuk proses selanjutnya (BIG, 2014).

\section{Hubungan Korelasi Indeks Vegetasi dengan Kerapatan Jenis}

Validasi data dilakukan dengan perhitungan kerapatan di lapangan dengan metode sampel plot pada 10 titik (di kawasan Romokalisari dan Tambak Wedi). Metode ini dilakukan dengan pemilihan titik secara acak (random) dengan ukuran sampel plot sebesar 10×10 meter. Data yang diambil berupa jumlah tegakan tiap plot.
Selanjutnya nilai kerapatan akan dikorelasikan dengan algoritma indeks vegetasi untuk mengetahui hubungannya. Berikut merupakan data kerapatan jenis dan indeks vegetasi pada tiap plot seperti Tabel 3 berikut:

Tabel 3. Data Nilai NDVI dan Kerapatan Jenis di Lapangan

\begin{tabular}{ccc}
\hline Plot & NDVI & $\begin{array}{c}\text { Kerapatan Jenis } \\
\text { (ind/m2) }\end{array}$ \\
\hline 1 & 0,658 & 0,51 \\
2 & 0,508 & 0,31 \\
3 & 0,579 & 0,38 \\
4 & 0,359 & 0,17 \\
5 & 0,591 & 0,36 \\
6 & 0,588 & 0,22 \\
7 & 0,750 & 0,42 \\
8 & 0,622 & 0,44 \\
9 & 0,650 & 0,49 \\
10 & 0,753 & 0,49 \\
\hline
\end{tabular}

Berikut adalah korelasi antara nilai NDVI dengan kerapatan jenis seperti Gambar 3 berikut:

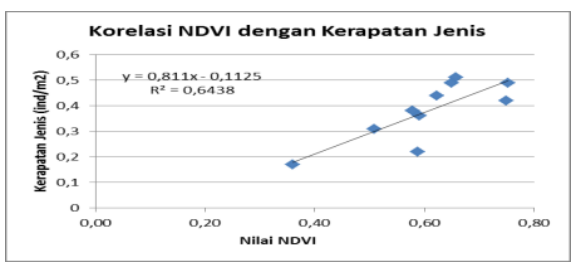

Gambar 3. Korelasi NDVI dengan Kerapatan Jenis

Dari perhitungan regresi linier diperoleh nilai $R^{2}$ pada parameter kerapatan jenis. Hasil korelasi NDVI dengan sampel kerapatan jenis menunjukkan bahwa nilai koefisien korelasi (R) antara nilai NDVI dan data lapangan sebesar 0,80. Hal ini menunjukkan korelasi yang sangat kuat (Landgrebe, 2003). Sehingga algoritma tersebut dapat digunakan untuk monitoring kerapatan mangrove.

\section{Hubungan Korelasi Indeks Vegetasi dengan Data Spectral Ground}

Tabel 4. Data NDVI Citra Landsat 8 dengan NDVI Foto

\begin{tabular}{ccccc}
\multicolumn{4}{c}{ Udara } \\
\cline { 1 - 3 } Titik & \multicolumn{2}{c}{ Koordinat } & NDVI & NDVI \\
\cline { 2 - 3 } & Timur $(\mathrm{m})$ & Utara $(\mathrm{m})$ & Citra & Foto \\
\hline F1 & 683505,00 & 9203815,00 & 0,543 & 0,279 \\
F2 & 683655,00 & 9203845,00 & 0,623 & 0,269 \\
F3 & 683655,00 & 9203815,00 & 0,767 & 0,338 \\
\hline
\end{tabular}

Hubungan antara nilai indeks vegetasi citra dengan data spectral ground foto udara dapat menggunakan uji korelasi. Pengambilan data 
spectral ground menggunakan kamera Infrared. Data spectral ground ini digunakan untuk mengecek prosentase kondisi lapangan. Tabel 4 menunjukkan hasil perhitungan NDVI citra serta foto udara.

Korelasi antara NDVI Citra Landsat 8 dengan data spectral ground foto udara adalah sebesar 0,89. Korelasi bertanda positif satu arah, sehingga jika nilai NDVI tinggi, begitu juga nilai spectral ground.

\section{Hubungan Korelasi Indeks Vegetasi dengan Sampel Parameter}

Beberapa faktor yang mempengaruhi kerapatan dan kesehatan mangrove adalah salinitas dan $\mathrm{pH}$. Pengambilan sampel air dilakukan di 3 titik pada tiap stasiun. Pengambilan sampel mewakili tiap zona. Lokasi pengambilan sampel berada dikawasan Romokalisari dan Tambak Wedi. Hasil pengukuran sampel lapangan seperti pada Tabel 5 berikut:

Tabel 5. Data Nilai NDVI dan Hasil Pengukuran Sampel Parameter Air

\begin{tabular}{ccccc}
\hline Lokasi & Plot & NDVI & $\begin{array}{c}\text { Salinitas } \\
\text { (ppt) }\end{array}$ & $\mathrm{pH}$ \\
\hline Stasiun I. & 1 & 0,658 & 20,80 & 7,35 \\
Tambak Wedi & 3 & 0,579 & 20,20 & 7,70 \\
& 4 & 0,359 & 19,90 & 7,60 \\
Stasiun II. & 5 & 0,591 & 5,00 & 7,30 \\
Romokalisari & 6 & 0,588 & 4,00 & 7,40 \\
& 10 & 0,753 & 6,00 & 7,30 \\
\hline
\end{tabular}

Pengukuran sampel di lapangan berada di dua lokasi yakni Tambak Wedi dan Romokalisari. Dari hasil pengukuran sampel air di lapangan, didapatkan data hasil pengukuran salinitas yang bervariasi antara 4,0-6,0 di stasiun Romokalisari dan 19,9-20,8 ppt di stasiun Tambak Wedi. Sedangkan nilai pH bervariasi antara 7,307,40 di stasiun Romokalisari dan 7,35-7,70 di stasiun Tambak Wedi. Perbedaan nilai salinitas dan $\mathrm{pH}$ tersebut dipengaruhi oleh perbedaan karakteristik lingkungan.

Hasil uji korelasi antara algoritma NDVI dengan sampel parameter salinitas di Tambak Wedi dan Romokalisari memiliki hubungan sangat kuat yakni 0,90 dan 0,87 . Hubungan korelasi tersebut bernilai positif, yang berarti semakin tinggi nilai NDVI citra maka nilai salinitas juga semakin tinggi. Sedangkan korelasi NDVI dan pH di Tambak Wedi dan Romokalisari sebesar -
0,48 dan -0,50. Nilai tersebut menunjukkan hubungan korelasi negatif antara NDVI dan $\mathrm{pH}$. Sehingga salinitas merupakan salah satu parameter yang berhubungan erat dengan kerapatan.

\section{KESIMPULAN}

Ekosistem mangrove yang ada di pesisir utara Surabaya terus mengalami penurunan luasan sejak tahun 2016-2018. Dari hasil perhitungan klasifikasi NDVI, luas mangrove berturut-turut sebesar $184,59,184,14$ dan 183,60 hektar. Total perubahan luas mangrove selama tahun 2016-2018 berdasarkan algoritma NDVI sebesar 0,99 hektar.

Untuk uji korelasi indeks vegetasi dengan sampel air, sampel salinitas berkorelasi lebih baik bila dibandingkan $\mathrm{pH}$. Salinitas berkorelasi positif dengan indeks vegetasi, artinya semakin tinggi nilai indeks vegetasi maka salinitas semakin tinggi. Korelasi yang dihasilkan $\mathrm{pH}$ bertanda negatif, apabila nilai indeks vegetasi semakin tinggi maka nilai $\mathrm{pH}$ sebaliknya. Sehingga parameter sampel air yang berhubungan dengan kerapatan adalah salinitas.

\section{DAFTAR PUSTAKA}

Abidin, H.Z. (2002). Survei dengan GPS. Jakarta : Pradnya Paramita.

Badan Informasi Geospasial. (2014). Peraturan Kepala BIG No. 15 Tahun 2014 tentang Pedoman Teknis Ketelitian Peta Dasar. Jakarta: BIG.

Danoedoro, P. (1996). Pengolahan Citra Digital Teori dan Aplikasinya dalam Bidang Penginderaan Jauh. Yogyakarta: Fakultas Geografi, Universitas Gajah Mada, Yogyakarta.

Ginting, dan Edina, E.B.R. (2004). Pemantauan Liputan Vegetasi Menggunakan Citra Satelit NOAAAVHRR (Studi Kasus P.jawa dan Madura). Tugas Akhir Fakultas Kehutanan. Yogyakarta: Universitas Gadjah Mada.

Landgrebe, D. (2003). Signal Theory Methods In Multispectral Remote Sensing. New Jersey: John Willey \& Sons Inc.

Ratnasari,D. dan Sukojo, B.M. (2017). Analisa Kondisi Ekosistem Mangrove Menggunakan Data Citra Satelit Multitemporal dan Multilevel (Studi Kasus : Pesisir Utara Surabaya). Surabaya: Departemen Teknik Geomatika, ITS.

Sugiyono. (2008). Metode Penelitian Kuantitatif Kualitatif dan R\&D. Bandung: Alfabeta. 